\title{
MENINGKATKAN HASIL BELAJAR IPA DENGAN METODE PRATIKUM MATERI POKOK MENUNJUKKAN PERBEDAAN SIFAT BENDA ( PADAT, CAIR, DAN GAS ) SISWA KELAS V SDN 021 KUNTO DARUSSALAM
}

\author{
WIGNYO \\ Guru SDN 021 Kunto Darussalam Rokan Hulu
}

\begin{abstract}
ABSTRAK
Penelitian ini dilakukan berdasarkan hasil observasi di kelas V ditemukan beberapa permasalahan yang terkait dengan hasil belajar Ipa siswa di kelas V. Penelitian ini bertujuan untuk mengetahui peningkatan hasil belajar Ipa siswa dengan menerapkan metode Pratikum Materi Pokok Menunjukkan Perbedaan Sifat Benda ( Padat, Cair, Dan Gas ) Siswa Kelas V Sdn 021 Kunto Darussalam T. A 2017/2018. Data dikumpulkan dengan menggunakan tes dan observasi. Penelitian ini dilaksanakan dalam dua siklus, yakni siklus I dan siklus II. Data dianalisis dengan menggunakan persentase dan analisis kualitatif. Berdasarkan analisis data, pada tes awal diperoleh Meningkatkan hasil belajar siswa pada siklus I rata-rata 75 dengan kategori baik, pada siklus II rata-rata meningkat 79,5 dengan kategori baik.Meningkatkan aktivitas guru pada siklus I rata-rata 80 dengan kategori baik, pada siklus II rata-rata 95 dengan kategori amat baik. Meningkatkan aktivitas belajar siswa pada siklus I 74,4 dengan kategori baik, pada siklus II meningkat menjadi 92,5 dengan kategori baik sekali. Meningkatkan ketuntasan hasil belajar siswa kelas V SD Negeri 021 Kunto Darussalam , yaitu sebelum perbaikan 23 siswa rata-rata $65 \%$, pada siklus I 26 siswa rata-rata $80 \%$, siklus II meningkat menjadi 28 siswa rata-rata 90\%.Berdasarkan temuan dari hasil penelitian dapat disimpulkan bahwa metode Pratikum dapat meningkatkan hasil belajar siswa pada mata pelajaran Ipa Materi Pokok Menunjukkan Perbedaan Sifat Benda ( Padat, Cair, Dan Gas ) Siswa Kelas V Sdn 021 Kunto Darussalam T. A 2017/2018.
\end{abstract}

\section{Kata Kunci: Hasil Belajar, Metode Pratikum, Penelitian Tindakan Kelas}

\section{PENDAHULUAN}

Pendidikan memiliki peranan penting bagi kehidupan manusia. Pendidikan mempengaruhi seluruh aspek kepribadian. pendidikan juga memiliki kekuatan yang dinamis. Melalui wadah ini seseorang dapat mengembangkan potensi secara optimal. Upaya meningkatkan potensi secara optimal itu dapat dilakukan dengan cara meningkatkan mutu pembelajaran.

Meningkatakan mutu pembelajaran dan hasil belajar peserta didik di kelas adalah salah satu upaya guru untuk menoptimalkan profesionalismenya sebagai tenaga pendidik dan kependidikan.

Tugas utama seorang guru adalah mengelola kegiatan belajar mengajar. Agar prosesnya berjalan secara optimal diperlukan banyak komponen pendukung antara lain sarana pembelajaran, perangkat pembelajaran, sumber belajar, metode-metode dan strategi pembelajaran, suasana lingkungan dan lain sebagainya. Menurut Suprayekti, (2008:226) kegiatan belajar mengajar adalah suatu kegiatan yang berlangsung selama kegiatan pembelajaran terjadi. Keberhasilan kegiatan belajar mengajar sering ditentukan oleh metode dan cara pembelajaran yang sesuai dengan karakteristik materi pembelajaran.

Slameto menambahkan bahwa belajar adalah proses usaha yang dilakukan seseorang untuk memperoleh suatu perubahan tingkah laku yang baru secara keseluruhan, sebagai hasil pengalamannya sendiri dalam interaksi dengan lingkungan (Slameto, 2003). Sementara pembelajaran adalah pengaturan lingkungan yang diarahkan untuk mengubah tingkah laku, perilaku siswa kearah positif dan lebih baik sesuai dengan potensi dan perbedaan yang dimiliki siswa. (Sanjaya, 2005).

Pendidikan di sekolah dasar dilaksanakan atas dasar kurikulum yang berlaku di sekolah. Hal ini memiliki makna yang strategis. Artinya, pendidikan di SD sangat menentukan sebagai peletak dasar ilmu pengetahuan dan teknologi (Iptek) dan pembentukan karakter peserta didik. Siswa juga akan dipersiapkan untuk menempuh pendidikan kejenjang yang lebih tinggi. Karena itu kompetensi/ kemampuan profesional guru 
SD harus ditingkatkan dan berkualitas agar pembelajaran berjalan secara produktif, aktif, kreaktif, efektif dan menyenangkan. Dari itu guru juga dapat melihat kelemahan-kelemahan pembelajaran yang terjadi di dalam kelas dan berupaya memperbaikinya.

Salah satu indikator kerja/mutu belajar pembelajaran yang berkualitas adalah hasil belajar siswa yang baik dalam artian secara umum siswa mencapai standar ketuntasan belajar minimal (SKBM) yang telah ditetapkan oleh sekolah umum untuk mata pelajaran tertentu.

Di SDN 021 Kunto Darussalam Kabupaten Rokan Hulu, khususnya untuk siswa kelas V, SKBM pada mata pelajaran IPA adalah 70 . Namun hasil belajar siswa dari ulangan semester setiap tahun ternyata masih jauh dari yang diharapkan. Banyaknya siswa yang belum mencapai SKBM rata-rata mencapai 71,67 pada mata pelajaran IPA. Karena itu hasil belajar siswa kelas V SDN 021 Kunto Darussalam secara umum masih perlu ditingkatkan melalui perbaikan pembelajaran.

Setelah dianalisis lebih lanjut, ditemukan bahwa salah satu materi pokok yang kurang dipahami siswa pada mata pelajaran IPA adalah Menunjukan Perbedaan Sifat Benda ( padat, Cair, dan Gas ). Karena rendahnya kemampuan dan hasil belajar siswa kelas V SDN 021 Kunto Darussalam pada materi di atas maka penelitian ini akan terfokus menyelesaikan masalah tersebut.

Selain masalah yang digambarkan di atas, pengalaman menunjukan bahwa dalam penerapan Kurikulum Tingkat Satuan Pendidikan (KTSP) disatu sisi, guru sering mengalami kendala/hambatan/masalah siswa kurang kreatif, pasif dan kurang bertanya dalam proses pembelajaran di ruang kelas. Disisi lain guru masih kurang pengalaman, wawasan, kreatifitas, dan daya inofatif dalam merancang dan menerapkan model/strategi pembelajaran, sehingga kegiatan belajar-mengajar yang diterapkan di dalam kelas masih didominassi oleh sistem pembelajaran konvensional (berpusat pada guru), bersifat informatif, penekanan pada belajar produk dan hafalan, kurang menarik, dan tidak melibatkan siswa dalam kegiatan belajar interaktif untuk menemukan sendiri konsep serta membangun pemahaman

dan mengembangkan kemampuannya secara baik.

Laporan ini disusun berdasarkan hasil observasi serta temuan-temuan yang diperoleh pada saat pelaksaan perbaikan pembelajaran yang dilakukan dalam dua siklus. Hasil pelajaran IPA dari 20 siswa, hanya 10 siswa yang menguasai dan terhitung tuntas sedangkan yang lain masih di bawah SKBM yang telah ditetapkan sekolah. Untuk memecahkan masalah ini, penulis melakukan penelitian untuk memperbaiki pembelajaran IPA khususnya pada materi pokok Menunjukan Perbedaan Sifat Benda ( padat, Cair, dan Gas ) dalam bentuk Penelitian Tindakan Kelas (PTK).

\section{Tujuan Penelitian Penelitian Perbaikan Pembelajaran}

Tujuan penelitian mengandung arti memperbaiki kinerja guru daalm proses pembelajaran dan meningkatkan belajar siswa dalam pembelajaran IPA. Guru harus dapat membangkitkan minat siswa karena guru sebagai motivasi yang mempengaruhi di dalam belajar, berpikir dan berprestasi (krap, Hidi, Reminger prudrich, dan schruk 1996). Oleh karena itu perencanaan perbaikan dilakukan melalui tahap identifikasi masalah, analisis, dan perumusan masalah. Selanjutnya dilakukan rencana perbaikan pembelajaarn yang di awasi pengawas.

Tujuan penelitian yang dilakukan pada SDN 021 Kunto Darussalam adalah Mendeskripsikan penerapan penggunaan metode pratikum pada materi pokok menunjukan perbedaan sifat benda (padat, cair, dan gas).

\section{KAJIAN PUSTAKA \\ Metode Pembelajaran}

Santoso berpendapat tentang metode, ( 2006 ; 2.26) adalah cara kerja yang bersistem untuk memudahkan pelaksanaan suatu kegiatan guna mencapai tujuan yang ditentukan. Bertitik tolak dari pendapat ini, maka metode khususnya dalam pembelajaran memainkan peranan yang cukup penting guna mencapai tujuan pembelajaran. Dalam proses pembelajaran penerapan suatu metode pembelajaran adalah sesuatu yang harus dilakukan guru, dengan metode yang tepat proses pembelajaran akan berlangsung secara optimal. Tidak jarang dalam 
proses pembelajaran guru menggunakan beberapa metode pembelajaran yang berbeda, tentu penggunaan metode yang berbeda tersebut sangat tergantung dari karakteristik siswa dan materi pembelajaran. Wahyudi (2007 ; 9.22), mengatakan upaya menggunakan metode secara kombinasi, pada saat guru sedang mengajar adalah penting dikembangkan.

\section{A. Metode Pratikum}

menjawab pertanyaan "bagaimana prosesnya? terdiri dari unsur apa? Cara mana yang lebih baik? Bagaimana dapat diketahui kebenaranya? yang semuanya didapatkan melalui pengamatan induktif'.

Praktikum Merupakan bentuk pengajaran yang kuat untuk membelajarkan keterampilan, pemahaman, dan sikap. Menurut Zaenuddin (1996) secara rinci praktikum dapat dimanfaatkan: Metode praktikum merupakan suatu cara penyajian bahwa pelajaran dan siswa melakukan percobaan dengan mengalami untuk membuktikan sendiri sesuatu pertanyaan atau hipotesis yang dipelajari dan sebagai salah satu mengajar dimana siswa melakukan suatu percobaan tentang suatu hal, mengamati prosesnya serta melakukan hasil suatu percobaan kemudian hasil pengamatan itu disampaikan di kelas dan dievaluasikan guru.

Menurut Soekarno dkk (1990 : 14) "metode praktikum adalah suatu cara mengajar yang memberi kesempatan kepada siswa untuk menemukan suatu fakta yang diperlukan atau ingin diketahuinya". Kegiatan praktikum pada dasarnya dapat digunakan untuk :

1. Mendapatkan atau menemukan suatu konsep, mencapai suatu definisi sampai mendapatkan dalil-dalil atau hukumhukum melalui percobaan yang dilakukannya.

2. Membuktikan atau menguji kebenaran secara nyata tentang suatu konsep yang telah dipelajari.

Menurut Djamarah dan Zain (2002:95) memberi pengertian bahwa metode praktikum adalah proses pembelajaran dimana peserta didik melakukan dan mengalami sendiri, mengikuti proses, mengamati obyek, menganalisis, membuktikan dan menarik kesimpulan suatu obyek, keadaan dan proses dari materi yang dipelajari tentang gejala alam dan interaksinya. Sehingga dapat

- untuk melatih keterampilanketerampilan yang dibutuhkan mahasiswa

- memberi kesempatan pada mahasiswa untuk menerapkan dan mengintegrasikan pengetahuan dan keterampilan yang dimilikinya secara nyata dalam praktek

- membuktikan sesuatu secara ilmiah atau melakukan scientific inquiry

- menghargai ilmu dan keterampilan dimiliki.

Praktikum dapat dilakukan pada suatu laboratorium atau diluar laboratorium, pekerjaan praktikum mengandung makna belajar untuk berbuat, karena itu dapat dimasukkan dalam metode pembelajaran.

beberapa pendapat diatas dapat ditarik suatu kesimpulan bahwa yang dimaksud dengan metode Pratikum adalah suatu cara guru mengajar dengan mempertunjukkan atau memperlihatkan kepada siswa tentang suatu proses atau cara kerja nyata ataupun tiruan. Metode pratikum tidak terlepas dari penjelasan secara lisan oleh guru, dalam strategi pembelajaran pratikum dapat digunakan untuk mendukung keberhasilan dengan tujuan pengajaran dan harapan siswa dapat memahami bahkan bisa melakukannya sendiri.

\section{Langkah-langkah Metode Pratikum :}

Djajadisastra (1982: 11) mengemukakan bahwa pada pelaksanaan praktikum agar hasil yang diharapkan dapat dicapai dengan baik maka perlu dilakukan langkah-langkah sebagai berikut :

\section{a. Langkah persiapan}

Persiapan yang baik perlu dilakukan untuk memperkecil kelemahankelemahan yang dapat muncul. Persiapan tersebut antara lain : menetapkan tujuan praktikum, mempersiapkan alat dan bahan yang diperlukan, mempersiapkan tempat praktikum, mempertimbangkan jumlah siswa dengan jumlah ketersediaan alat dan kapasitas tempat praktikum, mempersiapkan faktor keamanan dari praktikum, mempersiapkan tata tertib dan disiplin, serta 
membuat petunjuk dan langkah-langkah praktikum.

\section{b. Langkah pelaksanaan}

Sebelum melakukan praktikum, siswa mendiskusikan persiapan dengan guru setelah itu barulah meminta keperluan untuk praktikum. Selama proses melaksanakan metode praktikum, guru perlu melakukan observasi terhadap proses praktikum baik secara menyeluruh maupun perkelompok.

\section{c. Tindak lanjut metode praktikum \\ Setelah melaksanakan}

metode praktikum, kegiatan selanjutnya adalah meminta siswa membuat laporan praktikum, mendiskusikan masalah yang terjadi selama praktikum, dan memeriksa kebersihan alat dan menyimpan kembali semua perlengkapan yang telah digunakan.

\section{Media dalam Pembelajaran}

Peranan media dalam proses pembelajaran tidak perlu diragukan lagi, karena dengan penggunaan media pembelajaran yang tepat, proses transformasi pengetahuan dapat berjalan dengan cepat. Dalam konteks pembelajaran media dapat diartikan segala sesuatu yang dapat membantu jalannya proses pembelajaran, sehingga tujuan pembelajaran tercapai secara optimal. Hal ini sejalan dengan pendapat Arsyad (2007:20) yang mengatakan, media dalam proses pembelajaran cenderung diartikan sebagai alat-alat grafis, photografis, atau elektronis untuk menangkap, memproses, dan menyusun kembali informasi visual atau verbal, yang dapat membawa pesan-pesan atau informasi yang bertujuan unstuk instruksional atau mengandung maksud-maksud pengajaran. Laria (2008:45) mengatakan, media pembelajaran adalah semua alat bantu atau benda yang digunakan dalam kegiatan belajar mengajar dengan maksud untuk menyampaikan pesan informasi pembelajaran dari sumber (guru) maupun sumber lain kepada penerima (dalam hal ini anak didik ataupun warga belajar). Disisi lain media pembelajaran adalah segala sesuatu yang dapat menyalurkan pesan, dapat merangsang pikiran, perasaan dan kemampuan peserta didik sehingga dapat mendorong terciptannya proses belajar pada diri perserta didik.
Sudrajat, (2008:24) mengatakan, fungsi media pembelajaran antara lain, mengatasi keterbatasan pengalaman yang dimiliki oleh peserta didik, dapat melampaui batasan ruang kelas, memungkinkan adanya interaksi langsung antara peserta didik dengan lingkungannya, menghasilkan keseragaman pengamatan, menanamkan konsep yang benar, konkrit, dan realistis, membangkitkan, dan minat baru, motivasi, dan merangsang anak untuk belajar, memberikan pengalaman yang integral dari konkrit sampai dengan abstrak.

Salah satu media pembelajaran yang paling populer digunakan guru dalam melaksanakan proses pembelajaran adalah alat peraga. Alat peraga memiliki fungsi yang cukup strategis dalam pembelajaran diantarannya,

1. Memberikan penjelasan konsep.

2. Merumuskan atau membentuk konsep.

3. Melatih siswa dalam ketrampilan.

4. Memberikan penguasaan konsep pada siswa.

5. Melatih siswa dalam pemecahan masalah.

6. Mendorong siswa untuk berfikir secara rasional.

7. Mendorong siswa untuk melakukan pengamatan.

8. Melatih siswa untuk menemukan suatu ide baru dalam relasinya dengan konsep-konsep yang telah diketahui.

\section{PELAKSANAAN PENELITIAN \\ PERBAIKAN PEMBELAJARAN}

A. Subjek, Tempat, dan Waktu Penelitian, Pihak yang Membantu

1) Subjek Penelitian

Siswa kelas V pada SDN 021 Kunto Darussalam , Kecamatan Kunto, Kabupaten Rokan Hulu sebanyak 30 siswa yang terdiri dari 12 siswa dan 18 siswi.

2) Tempat

Tempat pelaksanaan tindakan kelas V SD Negeri 021 Kunto Darussalam Kabupaten Rokan Hulu. Alasan peneliti mengambil tempat penelitian di SD Negeri 004 adalah sebagai berikut :

a. Peneliti mengajar kelas V SD Negeri 021 Kunto Darussalam . Dalam kegiatan ini peneliti tidak 
mengganggu kegiatan belajar mengajar sekolah lain.

b. Tersedianya data yang diperlukan peneliti dalam melaksanakan kegiatan penelitian.
Penelitian

perbaikan pembelajaran ini terdiri dari 2 siklus, yakni siklus I dan siklus II, dan dilaksanakan pada semester genap tahun pelajaran

$2017 / 2018$.

\section{3) Waktu Penelitian}

Table 1. Jadwal Pelaksanaan Perbaikan Pembelajaran

\begin{tabular}{|c|c|c|c|c|c|}
\hline No & Tahap & Hari/Tanggal & Waktu & Mapel & Kelas \\
\hline 1 & Pra Siklus & $\begin{array}{c}\text { Senin, 02 } \\
\text { April 2018 }\end{array}$ & $\begin{array}{c}08.05- \\
09.15\end{array}$ & IPA & III \\
\hline \multirow{2}{*}{1} & $\begin{array}{c}\text { Siklus 1 } \\
\text { Pertemuan } \\
1\end{array}$ & $\begin{array}{c}\text { Kamis, 05 } \\
\text { April 2018 }\end{array}$ & $\begin{array}{c}08.05- \\
09.15\end{array}$ & IPA & III \\
\hline \multirow{2}{*}{2} & $\begin{array}{c}\text { Siklus 1 } \\
\text { Pertemuaan } \\
2\end{array}$ & $\begin{array}{c}\text { Senin, 09 } \\
\text { April 2018 }\end{array}$ & $\begin{array}{c}08.05- \\
09.15\end{array}$ & IPA & III \\
\hline 3 & $\begin{array}{c}\text { Siklus 2 } \\
\text { Pertemuan } \\
1\end{array}$ & $\begin{array}{c}\text { Kamis, 12 } \\
\text { April 2018 }\end{array}$ & $\begin{array}{c}08.05- \\
09.15\end{array}$ & IPA & III \\
\hline 4 & $\begin{array}{c}\text { Siklus 2 } \\
\text { Pertemuan } \\
2\end{array}$ & $\begin{array}{c}\text { Senin, 16 } \\
\text { April 2018 }\end{array}$ & $\begin{array}{c}08.05- \\
09.15\end{array}$ & IPA & III \\
\hline
\end{tabular}

\section{Pihak yang Membantu}

Pelaksanaan penelitian ini tidak terlepas oleh bantuan dari pihak lain, di antaranya adalah teman sejawat berlaku sebagai observer, supervisor, dan juga kepala sekolah, dan rekanrekan guru SDN 021 Kunto Darussalam .

\section{B. Desain Prosedur Perbaikan \\ Pembelajaran}

Perbaikan dilaksanakan dalam bentuk penelitian tindakan kelas (Classroom Action Research) guna mendapatkan hasil penelitian yang diharapkan dan kegiatan penelitian ini terarah dengan baik. Perbaikan pembelajaran dalam penelitian ini dilaksanakan rangkaian langkah-langkah (a Spiral Of Steps) yaitu langkah penelitian yang dikemukakan oleh Kurt Lewin (Me. Riff, 1992 21:22) sebagai berikut :

1. Perencanaan

2. Pelaksanaan

3. Pengamatan

4. Refleksi

Kegiatan perbaikan ini dilaksanakan dalam dua siklus. Siklus pertama dan siklus kedua. Pelaksanaan dalam setiap siklus meliputi perencanaan, pelaksanaan, pengamatan pengumpulan data/instrumen, dan refleksi. Perhatikan gambar 1 berikut.

\section{HASIL DAN PEMBAHASAN}

\section{A. Deskripsi Hasil Penelitian Perbaikan Pembelajaran}

Pelaksanaan tindakan pada penelitian ini terdiri dari empat kali pertemuan dan dua kali ulangan harian atau terdiri dari dua siklus. Ujian Harian I (UH) dan UH II dilakukan setelah dilaksanakan dua kali pertemuan pada kedua UH. Pelaksanaan tindakan ini menggunakan metode Pratikum pada materi pokok Mununjukan Perbedaan Sifat Benda ( Padat, Cair, dan gas ) di kelas V SDN 021 Kunto Darussalam tahun pelajaran 2017 / 2018. Pelaksanaannya melalui beberapa tahap:

\section{Siklus I (Kamis, 5 April 2016)}

Pada siklus I, tindakan dilakukan tiga kali pertemuan yang dibagi dalam dua kali tatap muka dan satu kali ulangan harian.

Siklus I dari kegiatan pembelajaran ini adalah pembahasan materi dari guru tentang "energi alternatif dan cara penggunaannya". Kegiatan Awal ( \pm 10 menit) guru dan siswa memulai pelajaran dengan salam dan doa. Kegiatan apersepsi dilakukan guru untuk 
bertanya siswa apakah mereka pernah melihat kincir air? Setelah kegiatan apersepsi ini, guru memotivasi siswa dengan memberikan informasi singkat tentang energi alternatif dan setelah itu menyampaikan tujuan pembelajaran

Kegiatan Inti $( \pm 45$ menit) guru bersama siswa membuat kapal layar sederhana dari kertas atau kincir angin sederhana dari akertas, siswa bertanya jawab tentang benda itu dan mengomentari kapal layar sederhana tersebut serta mengaitkan dengan pengetahuannya. Setelah itu siswa menempati kelompok yang sudah ditetapkan sebelumnya dan setiap kelompok mendapatkan LKS.

Pada kegiatan selanjutnya guru meminta siswa menyebutkan jenis-jenis lain dari energi alternatif dan bagaimana cara penggunaannya. Siswa menuliskan nama-nama energi alternatif itu dan membuat alat sederhana yang mampu memberikan energi alternatif. Setelah kegiatan itu, guru membimbing siswa mengerjakan LKS, kemudia setiap kelompok mempresentasikan hasil kerja kelompoknya dan siswa yang lain menanggapinya.

Guru menjelaskan kembali materi energi alternatif dan cara penggunaannya untuk selanjutnya bertanya jawab dengan siswa. Jawaban dari siswa yang kurang sempurna dilengkapi oleh guru.

Kegiatan Penutup $( \pm \quad 15$ menit $)$ membimbing siswa membuat simpulan pelajaran dan memberikan evaluasi soal postest untuk mengukur perkembangan hasil belajar pada pertemuan kedua siklus I. selanjutnya guru memberikan penguatan untuk pertemuan mendatang.

Setelah melakukan kegiatan pembelajaran, melakukan diskusi dengan pengamat pada Siklus I ini karena aktivitas siswa dan guru mengalami peningkatan signifikan dibandingkan pertemuan pertama. Kerjasama saat diskusi sudah mulai terbentuk antara teman sekelompok. Siswa yang tergolong pandai, mampu mengajari teman sekelompoknya yang tergolong kurang pandai. Tetapi masih juga dijumpai beberapa orang siswa yang hanya duduk dan diam melihat temannya bekerja, juga masih ada yang mainmain dalam berdiskusi ada juga siswa yang tidak pasif tidak bertanya bertanya atau menjawab pertanyaan yang diberikan guru terutama pada siswa yang berkemampuan rendah.

\section{Ulangan Harian I (Senin, 09 April 2018)}

Pada UH I siklus I dilaksanakan dengan materi energi alternatif, Pelaksanaannya dilaksanakan selama dua jam pelajaran atau $2 \mathrm{x}$ 35 menit dengan jumlah soal sebanyak 5 butir soal. Pada pelaksanaannya masih dijumpai siswa yang bekerjasama dengan teman sebangku, ada yang minta jawaban, dan ada yang menyontek. Hal semcam inilah yang perlu diatasi oleh guru. Upaya mengatasinya dengan memberi aturan agar dalam melaksankan UH tidak sama dengan diskusi kelompok, harus dikerjakan dengan kemampuan sendiri.

Setelah guru memberi arahan siswa kembali mengerjakan ulangan dengan tertib dan serius. Hingga pada waktu yang telah ditentukan guru, sebelum waktu belajar berakhir, guru mengumpulkan lembar soal dan lembar jawaban ulangan harian siswa.

\section{Refleksi Siklus I}

Setelah memperoleh data dari uraian proses pembelajaran, maka ada beberapa hal yang menjadi kekurangan dan kelemahan dalam pelaksanaan kegiatan ini:

a. Beberapa siswa masih acuh terhadap keterangan yang diberikan guru.

b. Sisiwa yang berkemampuan kurang, masih enggan untuk bertanya ataupun menjawab pertanyaan guru.

c. Siswa belum bisa memanfaatkan waktu saat LKS dibagikan sehingga waktu yang disediakan tidak cukup untuk menyelesaikan pertanyaan dalam LKS.

d. Beberapa siswa yang memiliki kemampuan tinggi, terlihat tetap aktif dan mendominasi jalannya diskusi sedangkan sebagaian siswa yang memiliki kemampuan kurang tidak fokus akan diskusi. Konsentrasinya beralih pada kegiatan main-main di kelas atau asik bercakap-cakap di luar tema diskusi.

Maka kekurangan dan kelemahan yang ditemui pada siklus I, menjadi pokok dasar untuk memperbaiki pembelajaran pada siklus II. Pokok yang akan diperbaiki adalah: 
a. Perlunya ketegasan guru dalam setiap kegiatan siswa di kelas terutama pada penetapan waktu pada tiap kegiatankegiatan yang akan dilaksanakan, sehingga waktu dapat dimanfaatkan dengan efesien.

b. Perlunya bimbingan guru secara merata kepada seluruh peseta didik di kelas, tidak hanya pada murid-murid tertentu.

c. Guru harus mampu membuat siswa untuk antusias bertanya tentang mateti yang disampaikan.

d. Selalu merespon pertanyaan dari siswa dengan bijak.

\section{Siklus II (Kamis, 12 April 2018)}

Seperti siklus pertama, siklus II juga dilakukan sebanyak tiga kali pertemuan, yaitu dua kali tatap muka dan satu kali Ulangan Harian.

Pada siklus II ini, kegiatan pembelajaran yang dibahas guru adalah "perubahan energi bunyi melalui penggunaan alat musik". Kegiatan Awal berlangsung lebih kurang 10 menit $( \pm 10$ menit) dimulai dengan salam dan do'a. guru melakukan apersepsi dengan bertanya apakah siswa punya gitar, biola atau seruling dan bisa memainkannya? Setelah itu guru memotivasi siswa dengan Informasi singkat perubahan energi bunyi melalui alat musik menyampaikan tujuan pembelajaran.

Kegiatan Inti $( \pm 45$ menit $)$, Guru memberikan pemahaman kepada siswa bahwa bunyi dapat merambat melalui benda gas, cair, ataupun juga benda padat. Kemudian meminta siswa untuk mengomentari jenis alat musik, atau benda-benda yang bisa dirambat oleh bunyi dan mengaitkan dengan pengetahuannya. Siswa bertanya jawab alat/benda-benda tersebut, siswa menempati kelompok yang sudah ditetapkan sebelumnya dan setiap kelompok mendapatkan LKS.

Guru meminta siswa menyebutkan bendabenda yang dapat menghasilkan bunyi atau alatalat musik yang biasa digunakan siswa yg dapat menghasilkan bunyi. Guru membimbing siswa mengerjakan LKS, setiap kelompok mempresentasikan hasil kerja kelompoknya dan siswa yang lain menanggapinya. Guru memandu jalannya presentasi dengan mengarahkan siswa untuk merumuskan jawaban yang benar. Sebelum kegiatan penutup guru menjelaskan materi tentang energi bunyi, siswa dan guru bertanya jawab tentang energi bunyi, guru meluruskan jawaban yang kurang sempurna.

Kegiatan Penutup ( \pm 15 menit), di bawah bimbingan guru siswa membuat simpulan pelajaran, guru memberikan soal evaluasi sebanyak 5 soal, guru memberikan penguatan kepada siswa untuk membaca buku dirumah karena pada pertemuan ketiga nanti akan diadakan UH II.

\section{Ulangan Harian II (Senin, 16 april 2016)}

Siklus II, UH II yang diikuti 20 orang siswa dilaksanakan dengan materi perubahan energi bunyi melalui penggunaan alat musik. Ulangan harian II dilaksanakan 2 jam pelajaran ( 2 x 35 menit) dengan jumlah soal sebanyak 5 soal. Pada pelaksanaan UH II semua siswa sudah mengerjakan soal dengan baik, tidak ada lagi siswa yang ingin mencontek buku atau meminta jawaban dari temannya, karena di awal pertemuan guru sudah memberi intruksi akan memberikan sanksi kepada siswa apabila kedapatan mencontek ataupun kompromi dengan temannya. Guru menyarankan agar mengerjakan soal yakin dengan pendapat sendiri. Lima menit sebelum waktu berakhir, guru mengumpulkan lembar jawaban dan lembar soal.

\section{Refleksi Siklus II}

Pada siklus II pembelajaran berjalan lebih baik dari siklus I, karena siswa sudah mengerti dengan langkah-langkah pembelajaran menggunakan LKS, sehingga membantu meminimalisasi kesalahan yang dilakukan siswa. Namun di sisi lain, masih ada beberapa siswa yang tidak melakukan kegiatan, tidak mendengarkan penjelasan guru, tidak bertanya dan menjawab pertanyaan. Siswa yang aktif dalam kegiatan Pembelajaran, selalu mampu mengerjakan LKS dan presentasi hasil kerja kelompok di depan kelas. Langkah guru selanjutnya dengan memberikan tugas untuk penguatan agar jangan lebih meningkatkan pemahaman terhadap pelajaran. Jadi, pada siklus II ini pelaksanaan proses pembelajaran sudah baik, meskipun ada kesalah dikarenakan guru kurang memotivasi atau memfasilitasi siswa untuk bretanya atau menjawab pertanyaan. Namun secara keseluruhan proses 
pelajaran pada siklus II ini sudah baik dan sesuai dengan perencanaan.

B. Pembahasan Hasil Penelitian Perbaikan Pembelajaran

Hasil pengamatan pada setiap siklus dapat dianalisis sebagai berikut :

1. Analisis Hasil Pengamatan Aktivitas Siswa Siklus I dan II

Adapun aktivitas siswa selama tindakan siklus I dan II dapat dilihat pada tabel di bawah ini:

Tabel 2. Aktivitas Siswa dalam Kegiatan Pembelajaran

\begin{tabular}{|c|c|c|c|c|c|c|c|c|}
\hline \multirow[t]{2}{*}{ Siklus } & \multicolumn{2}{|c|}{$\begin{array}{l}\text { Mendengarkan } \\
\text { penjelasan guru }\end{array}$} & \multicolumn{2}{|c|}{$\begin{array}{c}\text { Bertanya dan } \\
\text { menjawab } \\
\text { pertanyaan }\end{array}$} & \multicolumn{2}{|c|}{$\begin{array}{c}\text { Aktif dalam kegiatan } \\
\text { pembelajaran }\end{array}$} & \multicolumn{2}{|c|}{$\begin{array}{c}\text { Mengerjakan lks } \\
\text { dan presentasi } \\
\text { hasil kerja } \\
\text { kelompok }\end{array}$} \\
\hline & ya & tidak & ya & tidak & ya & tidak & ya & tidak \\
\hline $\mathrm{I}$ & $18(90 \%)$ & $2(10 \%)$ & $17(85 \%)$ & $3(15 \%)$ & $17(85 \%)$ & $3(15 \%)$ & $20(100 \%)$ & $-(0 \%)$ \\
\hline II & $20(100 \%)$ & 0 & $18(90 \%)$ & $2(10 \%)$ & $18(90 \%)$ & $2(10 \%)$ & $20(100 \%)$ & 0 \\
\hline
\end{tabular}

Dari tabel 2 di atas dapat dilihat bahwa aktivitas mendengarkan penjelasan guru sebanyak 18 (90\%) siswa yang melakukan aktivitas, aktivitas Bertanya dan menjawab pertanyaan sebanyak 17 (85\%), aktif dalam kegiatan Pembelajaran 17 (85\%) dan Mengerjakan LKS dan presentasi hasil kerja kelompok sebanyak 20 (100\%). Rata-rata aktivitas siklus I adalah 90\% dengan kategori Baik Sekali.

Pada siklus II, dapat dilihat bahwa aktivitas mendengarkan penjelasan guru sebanyak $20(110 \%)$ siswa yang melakukan aktivitas, aktivitas Bertanya dan menjawab pertanyaan sebanyak 18 (90\%), aktif dalam kegiatan Pembelajaran 18 (90\%) dan Mengerjakan LKS dan presentasi hasil kerja kelompok sebanyak 20 (100\%). Rata-rata aktivitas siklus I adalah 95\% dengan kategori Baik Sekali.

\section{Analisis Hasil Pengamatan Aktivitas Guru Siklus I dan II}

Aktivitas guru selama tindakan siklus I dan II dapat dilihat pada tabel di bawah ini:

Tabel 3. Aktivitas Guru dalam Kegiatan Pembelajaran

\begin{tabular}{|c|c|c|c|c|c|}
\hline \multirow{3}{*}{ No. } & \multirow{3}{*}{ Komponen Keterampilan } & \multicolumn{4}{|c|}{ Penilaian } \\
\hline & & \multicolumn{2}{|c|}{ Siklus I } & \multicolumn{2}{|c|}{ Siklus II } \\
\hline & & Ya & Tidak & Ya & Tidak \\
\hline 1. & Mengkondisikan kelas & $\checkmark$ & - & $\checkmark$ & - \\
\hline 2. & $\begin{array}{l}\text { Menghubungkan pelajaran sekarang dengan } \\
\text { pelajaran terdahulu }\end{array}$ & $\checkmark$ & - & $\checkmark$ & - \\
\hline 3. & Penguasaan Materi & $\checkmark$ & - & $\checkmark$ & - \\
\hline 4. & Memotivasi siswa untuk bertanya & $\checkmark$ & - & $\checkmark$ & - \\
\hline 5. & $\begin{array}{l}\text { Memotivasi siswa untuk menjawab } \\
\text { pertanyaan }\end{array}$ & - & $\checkmark$ & $\checkmark$ & - \\
\hline 6. & $\begin{array}{l}\text { Memotivasi siswa untuk melakukan aktivitas } \\
\text { dalam pembelajaran }\end{array}$ & $\checkmark$ & - & $\checkmark$ & - \\
\hline 7. & Kesesuaian media dengan materi & $\checkmark$ & - & $\checkmark$ & - \\
\hline 8. & Penggunaan metode demonstrasi & $\checkmark$ & - & $\checkmark$ & - \\
\hline 9. & Penggunaan waktu & $\checkmark$ & - & $\checkmark$ & - \\
\hline 10. & Pelaksanaan evaluasi & $\checkmark$ & - & $\checkmark$ & - \\
\hline \multicolumn{2}{|r|}{ Rata-rata } & 90 & 10 & 100 & $\mathbf{0}$ \\
\hline \multicolumn{2}{|r|}{ Kategori } & \multicolumn{2}{|c|}{ Baik Sekali } & \multicolumn{2}{|c|}{ Baik Sekali } \\
\hline
\end{tabular}


Dari tabel 3 di atas dapat dilihat bahwa aktivitas guru pada siklus I sudah mencapai 90\%, adapun aktivitas yang tidak dilaksanakan adalah memotivasi siswa untuk menjawab pertanyaan karena guru khawatir tidak mampu memaksimalkan waktu yang tersedia.

Pada siklus II aktivitas guru sudah mencapai $100 \%$ hal ini disebabkan guru sudah bisa memanfaatkan waktu untuk semua kegiatan sehingga aktivitas guru semuanya tercapai.

\section{Analisis Data Hasil Belajar}

a. Ketercapaian KKM

Jumlah siswa yang mencapai KKM berdasarkan hasil post test dapat dinyatakan dengan tabel berikut.

Tabel 4. Nilai Hasil Belajar Siswa yang Mencapai KKM Siklus I dan II

\begin{tabular}{|c|c|c|c|c|}
\hline \multirow{2}{*}{ No. } & \multirow{2}{*}{ Kategori } & \multicolumn{3}{|c|}{ Daya Serap } \\
\cline { 3 - 5 } 1. & Amat Baik & Skor Dasar & Siklus I & Siklus II \\
\hline \multirow{2}{*}{2.} & $85-100$ & $(15 \%)$ & 5 & 8 \\
& Baik & 10 & $(25 \%)$ & $(40 \%)$ \\
\hline \multirow{2}{*}{3.} & $70-84$ & $(50 \%)$ & 11 & 10 \\
& Cukup & 5 & $(55 \%)$ & $(50 \%)$ \\
\hline \multirow{2}{*}{4.} & $50-69$ & $(25 \%)$ & 3 & $(15 \%)$ \\
\hline & Kurang & 2 & 1 & - \\
\hline & $0-49$ & $(10 \%)$ & $(5 \%)$ & $\mathbf{2 0}$ \\
\hline & Jumlah Siswa & $\mathbf{2 0}$ & $\mathbf{2 0}$ & $\mathbf{7 9 , 5}$ \\
\hline
\end{tabular}

Ketuntasan hasil belajar siswa UH I siklus I berdasarkan tabel di atas, dari 30 siswa kelas $\mathrm{V}$ terdapat 26 siswa yang mencapai KKM dengan persentase $80 \%, 4$ siswa tidak mencapai KKM dengan persentase $20 \%$. Pada siklus I ini, hasil belajar siswa belum dinyatakan tuntas.

Pada UH II siklus II, pencapaian mengalami perubahan yang signifikan, siswa yang sudah mencapai KKM sebanyak 28 siswa dengan persentase $90 \%$ dan yang tidak mencapai KKM 2 siswa dengan persentase 10\%. Ditinjau secara klasikal hasil belajar siswa dinyatakan telah tuntas. Ketuntasan mata pelajaran IPA adalah 70. Sedangkan 2 siswa yang belum mencapai KKM diberikan guru program remedial.

\section{b. Analisis Keberhasilan Tindakan}

Hasil Peningkatan belajar siswa kelas V SD N 021 Kunto Darussalam dari 20 orang, bahwa siswa yang belum mencapai KKM pada skor dasar adalah 7 orang dan mengalami penurunan menjadi 4 orang pada siklus I dan siklus II 2 orang. Peningkatan jumlah siswa yang mencapai KKM dari skor dasar ke siklus I dan siklus II. Skor dasar menunjukkan bahwa 23 orang siswa mengalami peningkatan pencapaian KKM menjadi 26 orang pada siklus
I sedangkan siklus II menjadi 28 orang. Berarti nilai siswa sudah mengalami peningkatan.

Menurut Hamlik (1994) memberi batasan media pendidikan adalah alat, metode dan teknik digunakan dalam rangka mengaktifkan komunikasi dan interaksi antar guru dan siswa dalam proses pendidikan dan pengajaran disekolah".

Berikut ini adalah tabel daftar distribusi frekuensi nilai hasil belajar Siswa dalam bentuk grafik:

\section{Grafik 1. Hasil Belajar Siswa Sebelum Perbaikan, Siklus I dan Siklus II}

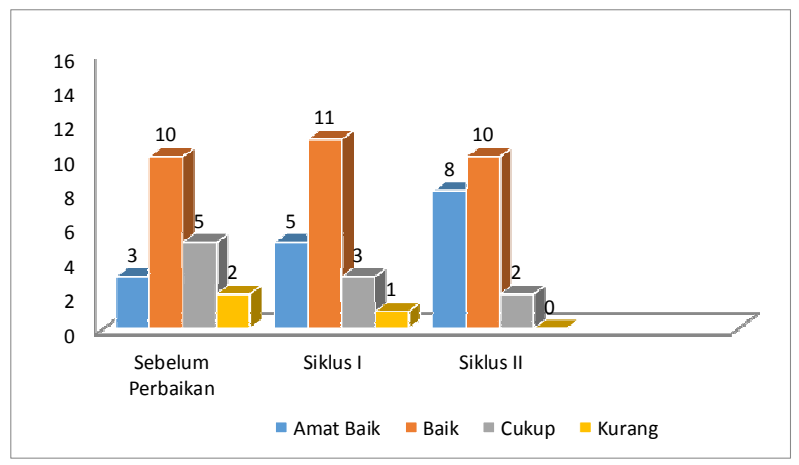

Grafik di atas menunjukkan bahwa nilai UH sebelum perbaikan rata-rata 67 dengan kategori (Cukup), siklus I dengan nilai rata-rata 75 dengan kategori (Baik ), siklus II mengalami 
peningkatan menjadi 79,5 dengan kategori (Baik). Hasil analisis data telah menunjukkan hasil belajar dan aktivitas siswa meningkat dari siklus I dan siklus II. Peningkatan hasil belajar siswa bersinergi dengan meningkatnya aktivitas guru dalam membentuk suasana belajar yang kreatif dan didukung pula dengan media, materi dan tujuan belajar yang sesuai.

\section{Daya serap siswa semakin meningkat} dengan metode demonstrasi dalam pembelajaran IPA karena metode ini menuntut siswa aktif terlibat dalam suasana pembelajaran yang menyenangkan. Pembelajaran IPA dengan metode ini juga mampu memotivasi kreativitas siswa ditambah lagi dengan adanya diskusi kelompok dalam mengerjakan LKS dari guru. Kerjasama kelompok dalam mengerjakan LKS dapat membantu siswa yang lemah daya serapnya karena dibantu secara langsung oleh siswa yang lebih pintar, sehingga apa yang diajarkan guru bisa dengan mudah dikuasai.

Analisis data di atas menunjukkan bahwa hasil belajar dan aktivitas siswa meningkat dari siklus I, ke siklus II. Peningkatan aktivitas guru dalam menciptakan suasana pembelajaran yang lebih menarik, media yang tepat, dan sesuai dengan tujuan pembelajaran mendukung tingkat pemahaman siswa.

Upaya-upaya yang dilakukan guru dengan berbagai hal seperti memberikan motivasi, arahan, dan bimbingan yang inten kepada siswa terutama pada siswa yang mengalami kesulitan belajar, akan berdampak positif jika dilakukan dengan pembelajaran yang lebih baik. Maka ketuntasan pelajaran IPA siswa kelas V SDN 021 Kunto Darussalam secara klasikal meningkat dari siklus I rata-rata ketuntasan $80 \%$ menjadi $90 \%$ pada siklus II.

Dapat disimpulkan bahwa hipotesis tindakan yang diajukan dapat diterima kebenarannya dengan kata lain pengunaan metode pratikum dapat meningkatkan hasil belajar IPA siswa kelas V SDN 021 Kunto Darussalam Tahun Pelajaran 2017/2018 khususnya pada materi pokok menunjukkan perbedaan sifat benda ( padat, cair, dan gas ).

\section{SIMPULAN}

Dari hasil penelitian dapat disimpulkan bahwa penggunaan metode pratikum sebagai media pembelajaran dapat :

1. Meningkatkan hasil belajar siswa pada siklus I rata-rata 75 dengan kategori baik, pada siklus II rata-rata meningkat 79,5 dengan kategori baik.

2. Meningkatkan aktivitas guru pada siklus I rata-rata 80 dengan kategori baik, pada siklus II rata-rata 95 dengan kategori amat baik.

3. Meningkatkan aktivitas belajar siswa pada siklus I 74,4 dengan kategori baik, pada siklus II meningkat menjadi 92,5 dengan kategori baik sekali.

4. Meningkatkan ketuntasan hasil belajar siswa kelas V SD Negeri 021 Kunto Darussalam , yaitu sebelum perbaikan 23 siswa rata-rata $65 \%$, pada siklus I 26 siswa rata-rata $80 \%$, siklus II meningkat menjadi 28 siswa rata-rata $90 \%$.

\section{DAFTAR PUSTAKA}

$\mathrm{http}: / / \mathrm{www}$.marioatha.com/2014/04/pengertianmetode-praktikum-menurut-para-ahli.html. ( Di Unduh Tanggal 10 April Pukul 12:28 Wib ). Kota Lama. Riau

http://digilib.unila.ac.id/15190/3/langkahlangkah-metode-pratikum.pdf

( Di Unduh Tanggal 10 April Pukul 13 : 16 Wib ). Kota Lama. Riau

Andayani, dkk. (2011). Pemantapan Kemampuan Profesionasl. Jakarta : Universitas Terbuka

Arsjad, G Maida dan Mukti US. (1991). Pembinaan Kemampuan Berbicara Bahasa Indonesia. Jakarta : Erlangga Jurnal Pendidikan Widya Tama, Volume 2 No. 4. Desember (2005). Semarang: $\quad$ LPMP Jawa Tengah

Asma. Nur. (2006). Model Pembelajaran Kooperatif. Jakarta : Depdiknas.

BSNP. (2006). Panduan Penyusunan KTSP Jenjang Pendidikan Dasar dan Menengah. Jakarta : Depdiknas.

Hamalik. Oemar. (2001). Proses Belajar Mengajar. Jakarta : Bumi Aksana.

Majid, Abdul. (2008).Perencanaan Pembelajaran. Bandung: PT Remaja Rosdakarya 
Satori, Djam'an. (2009). Profesi Keguruan. Jakarta : Universitas Terbuka.

Taufik, Agus. (2010) .Pendidikan Anak di SD. Jakarta : Universitas.

Wardhani, I.G.A.K. dkk. (2008). Penelitian

Tindakan Kelas. Jakarta : Universitas Terbuka.

Winataputra, Udin S. dkk. (2007. Strategi Belajar Mengajar. Jakarta : Universitas Terbuka.

Winataputra, Udin S. dkk. (2007. Teori Belajar dan Pembelajaran. Jakarta: Universitas

Terbuka.

Munadi, Yudhi. (2008). Media Pembelajaran, Sebuah Pendekatan Baru. Ciputat :

Gaung Persada Press

Denny Setiawan. 2007. Komputer dan Media

Pembelajaran. Jakarta : universitas Terbuka.

Edgar Dale. 2008. Media Pembelajaran.

Jakarta. Dekti. Depdiknas. 